\title{
MEKANISME PENYELESAIAN PERKARA PELANGGARAN KODE ETIK PROFESI POLRI DALAM KASUS PENIPUAN DAN PENGGELAPAN YANG DILAKUKAN OKNUM POLRI (Studi Kasus di Polres Banjarbaru Kalimantan Selatan)
}

\author{
Safitri Wikan Nawang Sari \& Eroy Aryadi \\ Fakultas Hukum Universitas Achmad Yani Banjarmasin \\ E-mail : sawinari@gmail.com
}

\begin{abstract}
ABSTRAK
Adanya keterlibatan oknum Anggota Polri Polres Banjarbaru berinisial AIPTU M, yang melakukan suatu tindak pidana penipuan dan penggelapan sesuai pasal 372 dan 378 KUHP. Adapun untuk tujuan dari penulisan ini adalah : (1) Sebagai pedoman dan keseragaman administrasi Penyidik Propam Polri dalam menjalankan tugasnya melakukan penyidikan perkara pelanggaran disiplin, pidana dan kode etik di lingkungan Kepolisian Republik Indonesia sesuai dengan SOP (Standar Operasional Prosedur); (2) Memberikan kejelasan tentang Peraturan Pemerintah Republik Indonesia (PPRI) No. 2 Tahun 2003 tentang Peraturan Disiplin Anggota Kepolisian Negara Republik Indonesia yang bersinergi dengan Surat Edaran Kapolri Nomor 6 Tahun 2014 tentang Teknis Pelaksanaan Penegakan Pelanggaran Kode Etik Profesi Polri sehingga para penyidik Propam mampu bertindak secara professional, Modern dan Terpercaya.

Metode Penelitian yang digunakan dalam penelitian ini adalah metode penelitian empiris dengan pendekatan sosiologis, karena bahan hukum diperoleh langsung dari fakta-fakta yang ada dalam suatu masyarakat, badan hukum atau badan pemerintah.Pengumpulan data melalui studi kasus, penelitian dilapangan, dan wawancara.

Hasil penelitian ini adalah : (1) Penyelesaian Perkara Pelanggaran Kode Etik Profesi Polri yang dilakukan oknum berinisial Aiptu M dengan korban An. NOERANA diarahkan agar melaporkan pengaduan nya ke Sentra Pelayanan Kepolisian Terpadu (SPKT) Polres Banjarbaru dikarenakan ditemukannya unsur pidana dalam pelanggaran yang dilakukan oleh oknum berinisial AIPTU M, namun yang bersangkutan tidak mau melaporkan kasus pidananya dan hanya berharap disidangkan disiplin saja, padahal sesuai dengan Surat Edaran Kapolri Nomor : SE/6/V/2014 tentang Tekhnis Pelaksanaan Penegakan Pelanggaran Kode Etik Profesi Polri bahwa agar Fungsi Propam segera melimpahkan ke Fungsi Reskrim terhadap hasil pemeriksaan apabila ditemukan bukti permulaan yang cukup suatu perbuatan tindak pidana yang dilakukan oleh personil Polri, sesuai ketentuan hukuman disiplin tidak menghapuskan tuntutan pidana, adapun Tata Cara Penyelesaian Pelanggaran Disiplin di Institusi Polri sesuai dengan Perkap Kapolri Nomor 2 Tahun 2016 tentang Penyelesaian Pelanggaran Anggota Polri; (2) Oknum Polri berinisial AIPTU M, terduga pelanggar dihadapkan pada sidang
\end{abstract}


disiplin karena dipersangkakan telah melanggar peraturan disiplin berupa setiap anggota Polri dilarang "Melakukan hal-hal yang dapat menurunkan kehormatan dan martabat negara pemerintah atau polri.", sebagaimana dimaksud dalam Pasal 5 huruf(a) PP RI Nomor 2 tahun 2003 tentang peraturan disiplin bagi anggota Polri,dan dijatuhi hukuman berupa Mutasi yang bersifat demosi sesuai Keputusan Hukuman Disiplin Nomor : Kep / 9 / IX / 2018/ Seksi Propam Polres Banjarbaru, terkait adanya korban lain yang melaporkan permasalahan yang sama melalui jalur perkara pidana, sampai dengan sekarang Sat Reskrim Polres Banjarbaru masih melakukan penyidikan, pengumpulan alat bukti dan pemeriksaan saksisaksi, melaksanakan gelar perkara untuk naik penyidikan dan meminta pendapat, saran hukum, kepada korban sebagai pelapor nantinya diberikan haknya berupa Surat Tanda Penerimaan Laporan (STPL) dan Surat Pemberitahuan Perkembangan Hasil Penyidikan (SP2HP) apabila sudah dinyatakan 2 (dua) bukti permulaan yang cukup dan layak naik ke penyidikan oleh penyidik Sat Reskrim Polres Banjarbaru.

Kata Kunci : Penyelesaian Perkara, Pelanggaran, Disiplin, Kode Etik Kepolisian

\section{A. PENDAHULUAN}

Kepolisian Negara Republik Indonesia sebagai bagian dari sistem penegakan hukum (criminal justice system) telah berupaya berkontribusi menciptakan kultur yang baik dan bersih dalam melakukan kewajibannya juga menciptakan rasa percaya (trust) di dalam kehidupan bermasyarakat.

Tetapi dilain sisi, terbukti bahwa ada dampak yang buruk terhadap pelaksanaan tugas dan kewajiban yaitu kriminalisasi hukum, penyalahgunaan kekuasaan, diskriminasi dalam bidang hukum, dan berbagai perbuatan buruk lainnya, perkembangan situasi kamtibmas di wilayah Indonesia senantiasa mengalami peningkatan baik berupa kejahatan konvensional maupun permasalahan yang berimplikasi kontijensi (berkelanjutan) seperti pekat, narkoba, curat, curas, harus semakin disiplin, cerdas, berbudaya, berakhlak, bermoral kreatif dan inovatif dalam menjawab semua tantangan tugas yang dihadapi, hal tersebut tidak menutup kemungkinan akan semakin membuat peningkatan pelanggaran kode etik anggota Polri.

Suatu organisasi selalu mempunyai aturan sendiri dalam rangka meningkatkan kinerja, profesionalisme, budaya organisasi maupun kebersamaan, kehormatan dan kredibilitas organisasi tersebut serta untuk menjamin 
terpeliharanya tata tertib dan pelaksanaan tugas sesuai tujuan, peranan, fungsi, wewenang dan tanggung jawab institusi tersebut.

Dalam hal ini kredibilitas dan komitmen anggota Kepolisian Negara Republik Indonesia sebagai pejabat negara yang diberi tugas dan kewenangan selaku pelindung, pengayom, dan pelayan masyarakat, penegak hukum dan pemelihara keamanan dengan diikat Peraturan Disiplin Anggota Kepolisian Negara Republik Indonesia. Peraturan disiplin yakni serangkaian norma untuk membina, menegakkan disiplin dan memelihara tata tertib kehidupan anggota Kepolisian Negara Republik Indonesia. Pelanggaran Peraturan Disiplin adalah ucapan, tulisan, atau perbuatan anggota Kepolisian Negara Republik Indonesia yang melanggar peraturan disiplin.Tindakan disiplin adalah serangkaian teguran lisan dan/atau tindakan fisik yang bersifat membina, yang dijatuhkan secara langsung kepada anggota Kepolisian Negara Republik Indonesia. ${ }^{47}$ Peraturan Pemerintah ini berlaku bagi Anggota Kepolisian Negara Republik Indonesia, dan mereka yang berdasarkan peraturan perundang-undangan tunduk pada hukum yang berlaku bagi anggota Kepolisian Negara Republik Indonesia (Pasal 1 Peraturan Pemerintah Republik Indonesia Nomor 2 Tahun 2003).

Penyimpangan perilaku anggota kepolisian adalah perbuatan yang melanggar peraturan disiplin kepolisian yang telah diatur dalam Peraturan Pemerintah Republik Indonesia (PPRI) No. 2 Tahun 2003 tentang Peraturan Disiplin Anggota Kepolisian Negara Republik Indonesia. Berdasarkan rumusan pasal 1 angka 3 PPRI No. 2 Tahun 2003 tentang Peraturan Disiplin Anggota Kepolisian Negara Republik Indonesia adalah penegakan, pembinaan kedisiplinan serta pemeliharaan dalam hal tata tertib anggota kepolisian. Peraturan Disiplin Anggota Kepolisan Negara Republik Indonesia tidak hanya didasarkan pada kebutuhan profesional, tetapi juga telah diatur secara normatif dalam Undangundang No 2 Tahun 2002 tentang Kepolisian Negara Republik Indonesia yang ditindaklanjuti dengan terwujudnya Peraturan Pemerintah Republik Indonesia No 2 Tahun 2003 Tentang Peraturan Disiplin Anggota Kepolisian Negara Republik

\footnotetext{
47 “ Peraturan Pemerintah Republik Indonesia No 2 Tahun 2003 Tentang Disiplin Bagi Anggota Polri “
} 
Indonesia, dalam Pasal 4 UU No. 2 Tahun 2002 menjelaskan kepolisian mempunyai tujuan guna menciptakan kamtibmas dan ditegakkannya hukum, terciptannya pengayoman, perlindungan dan pelayanan masayarakat, dan diakuinya HAM. Banyaknya kasus pelanggaran disiplin \& pidana yang dilakukan oleh Anggota Polri menunjukkan bahwa belum profesionalnya anggota kepolisian, hal tersebut menghasilkan kekecewaan di dalam masyarakat tentang visi, misi, tugas, kewenangan yang dimiliki oleh Kepolisian Negara Republik Indonesia (Polri), Kondisi melemahnya disiplin dan profesionalisme anggota Polri yang terjadi pada saat ini mulai sering menjadi pembicaraan masyarakat luas. Dengan sering diberitakannya di berbagai media massa mengenai tindakan indisipliner yang dilakukan oleh anggota Polri, misalnya banyaknya kasus penyalahgunaan senjata api oleh anggota Polri, adanya anggota Polri yang terlibat dalam tindak pidana, tindakan sewenang-wenang anggota Polri, dan masih banyak kasus lain yang menggambarkan kurang disiplinnya anggota Polri, menjadikan keprihatinan sendiri bagi masyarakat terkait dalam pelaksanaan tugas pokok Polri yaitu menjaga keamanan dan ketertiban masyarakat, tertib dan tegaknya hukum, terselenggaranya perlindungan, pengayoman, dan pelayanan kepada masyarakat, serta terbinanya ketentraman masyarakat dengan menjunjung tinggi hak asasi manusia. $^{48}$

Menjawab semua tantangan tersebut diatas serta menciptakan postur Polri yang ideal dari SDM Polri, diperlukan sikap disiplin dari seluruh Anggota Polri, guna mewujudkan organisasi yang semakin profesional, modern, terpercaya dan proporsional dan prosedural yang didukung oleh nilai-nilai dasar yang terkandung dalam Tribrata (Pedoman Hidup Polri) dan Catur Prasetya (Pedoman Kerja Polri):

Tribrata (Pedoman Hidup Polri) dan Catur Prasetya (Pedoman Kerja Polri) dijabarkan dalam kode etik profesi Kepolisian Negara Republik Indonesia sebagai norma berperilaku yang patut dan tidak patut, bahwa penegakan kode etik profesi Polri harus dilaksanakan secara obyektif, akuntabel, menjunjung tinggi kepastian hukum dan rasa keadilan (legal and legitimate), serta hak asasi manusia dengan

${ }^{48}$ A Kadarmanta, 2011, Membangun Kultur Kepolisian, Forum Media Utama, Jakarta, hal 23 
memperhatikan jasa pengabdian anggota Polri yang diduga melanggar kode etik profesi Polri. $^{49}$

The standards of professional behaviour, as reflected in the Code of Ethics, are a statement of the expectations that the police and the public have of how police officers should behave. They are not intended to describe every situation but rather to set a framework which everyone can easily understand. They enable everybody to know what type of conduct by a police officer is acceptable and what is unacceptable. Thestandards should be read and applied having regard to the Code of Ethics ${ }^{50}$,

(Terjemahan bebasnya adalah Standar perilaku profesional, sebagaimana tercermin dalam Kode Etik, adalah pernyataan dari harapan yang dimiliki polisi dan masyarakat tentang bagaimana seharusnya petugas polisi berperilaku. Mereka tidak dimaksudkan untuk mendeskripsikan setiap situasi tetapi lebih untuk menetapkan kerangka kerja yang dapat dipahami semua orang dengan mudah. Mereka memungkinkan semua orang tahu apa jenis perilaku yang dilakukan oleh seorang petugas polisi dapat diterima dan apa yang tidak dapat diterima. Itu standar harus dibaca dan diterapkan dengan memperhatikan Kode Etik).

Dari pernyataan tersebut diatas menjelaskan bahwa harapan masyarakat cukup besar terhadap seorang anggota Polri, bagaimana harus bersikap professional, sopan, santun dan ramah serta dapat menjadi contoh teladan yang baik bagi masyarakatnya. Pakar hukum Satjipto Rahardjo mengatakan bahwa :

Implementation of restorative justice in the judicial system, especially at the level of investigation by the Police of the Republic of Indonesia, viewed from a legal perspective, the police work is nothing but the application or enforcement of the law, in other words the police become the status quo of the law. From this itshows that the duty of the police must be in line with what is required by the

\footnotetext{
49، Peraturan Kepala Kepolisian Negara Republik Indonesia Nomor 14 Tahun 2011 tentang Kode Etik Profesi Polri “

50. https://assets.publishing.service.gov.uk/government/uploads/system/uploads/attachment data/ file/330235/MisconductPerformAttendanceJuly14.pdf, 22 Nopember 2018, (22.30 wita)
} 
material criminal law and the formal criminal law, so that the law becomes the central point and make the Police as the legal servant itself. According to Satjipto Rahardjo such policing style, known as the "Antagonist Police" is the police who position themselves against the people. From this the police need to look at the principles that exist within the community itself, so that the police can put the people as its center is not just based on the law alone ${ }^{51}$. (Terjemahan bebasnya adalah Implementasi keadilan restoratif dalam sistem peradilan, terutama pada tingkat penyidikan oleh Kepolisian Republik Indonesia, dilihat dari perspektif hukum, pekerjaan polisi tidak lain adalah penerapan atau penegakan hukum, dengan kata lain polisi menjadi status quo hukum. Hal ini menunjukkan bahwa tugas polisi harus sesuai dengan apa yang dituntut oleh hukum pidana material dan hukum pidana formal, sehingga hukum menjadi titik sentral dan menjadikan Polisi sebagai hamba hukum itu sendiri.Menurut Satjipto Rahardjo gaya kepolisian seperti itu, dikenal sebagai "Polisi Antagonis" adalah polisi yang memposisikan diri terhadap rakyat. Dari sini polisi perlu melihat prinsip-prinsip yang ada di dalam masyarakat itu sendiri, sehingga polisi dapat menempatkan rakyat sebagai pusatnya bukan hanya berdasarkan pada hukum semata).

Dari pernyataan tersebut diatas dapat dinyatakan bahwa institusi Polri harus mampu menjadi teladan yang baik dengan menciptakan Polisi yang profesional, modern dan terpercaya yang bisa merebut kepercayaan masyarakat dalam penegakan hukum dan keadilan di Indonesia tidak malah mencederai supremasi hukum dengan segala macam perilaku penyimpangan yang tidak sesuai dengan harapan masyarakat kepada institusi Polri/aktor antagonis dalam sistem penegakan hukum.

Kasus yang saat ini masih hangat dan diperdebatkan yaitu adanya keterlibatan oknum Anggota Polri Polres Banjarbaru berinisial AIPTU M telah melakukan suatu tindak pidana yakni tindak pidana penipuan dan penggelapan sesuai pasal 372 KUHP (perbuatan mengambil barang milik orang lain sebagian

\footnotetext{
${ }^{51}$ http://www.iosrjournals.org/iosr-jhss/papers/Vol.\%2023\%20Issue6/Version-2/A2306020109.pdf, 22 Nopember 2018, (22.30 wita)
} 
atau seluruhnya dimana penguasaan atas barang itu sudah ada pada pelaku) dan pasal 378 KUHP (dengan maksud untuk menguntungkan diri sendiri atau orang lain secara melawan hukum, dengan memakai nama palsu atau martabat palsu dengan tipu muslihat, ataupun rangkaian kebohongan, menggerakkan orang lain untuk menyerahkan barang sesuatu kepadanya, atau supaya memberi hutang maupun menghapuskan piutang) ${ }^{52}$, adapun modus dan kronologisnya AIPTU M menjalankan usaha/bisnis rental mobil dengan cara join income (sistem bagi hasil), yaitu masyarakat yang berminat bisa menitipkan mobilnya ke rental yang dimiliki /dikelola dengan perjanjian keuntungan dibagi setengah anatara AIPTU M dan pemilik mobil, dan pada kenyataannya mobil yang dititipkan ke AIPTU M malah digadaikan kepada orang lain dengan tujuan menutupi bagi hasil yang sudah disepakati sebelumnya dengan para pemilik mobil yang menitipkan mobilnya di rental AIPTU M, akibat perbuatannya masyarakat yang dirugikan melaporkan ke Seksi Propam dan Sentra Pelayanan Kepolisian Terpadu (SPKT) Polres Banjarbaru.

\section{B. PERUMUSAN MASALAH}

Berdasarkan uraian pada latar belakang tersebut diatas, maka rumusan masalah yang diajukan dalam penelitian ini adalah sebagai berikut :

Bagaimana mekanisme penyelesaian perkara pelanggaran kode etik profesi polri dalam kasus penipuan dan penggelapan oleh oknum polri berinisial AIPTU $\mathrm{M}$ ?

\section{METODE PENELITIAN}

Jenis penelitian ini empiris sosiologis untuk melihat hukum dalam artian nyata dan meneliti bagaimana bekerjanya hukum di lingkungan masyarakat. Dalam penelitian ini meneliti orang dalam hubungan hidup di masyarakat maka metode penelitian hukum empiris dapat dikatakan sebagai penelitian hukum

\footnotetext{
${ }^{52}$ https://www.hukumonline.com/klinik/detail/lt4ceb3048897ea/penggelapan-dan-penipuan, Nopember 2018, (22.30 wita)
} 
sosiologis. ${ }^{53}$ Penelitian hukum yang diambil dari fakta-fakta yang ada di dalam suatu masyarakat, badan hukum atau badan pemerintah bersifat deskriptif yang mendeskripsikan suatu gejala, peristiwa, kejadian yang terjadi saat sekarang secara sistematis, faktual dan akurat terhadap suatu populasi atau daerah tertentu, mengenai karakteristik, atau faktor-faktor tertentu. Penelitian deskriptif dimaksudkan untuk memberikan data yang seteliti mungkin tentang manusia, keadaan atau gejala-gejala lainnya. Lokasi di Seksi Propam Kepolisian Resort Kota Banjarbaru, dengan alasan Seksi Propam Polres Banjarbaru sedang menyelesaikan perkara pelanggaran salah satu personilnya yaitu AIPTU M. Mengacu pada sumber data primer dalam menemukan kebenaran dengan menggunakan metode berpikir induktif dan kriterium kebenaran koresponden serta fakta yang digunakan untuk melakukan proses induksi dan pengujian kebenaran secara koresponden adalah fakta yang mutakhir, data yang diperoleh langsung dari kehidupan masyarakat dengan cara wawancara, observasi, kuesioner dan sample, meskipun tidak menafikkan data sekunder sebagai bukti untuk suatu pengujian. Pengolahan dan analisa data secara kualitatif induktif melalui 4(empat) tahapan yaitu pengumpulan data/ fakta dilapangan, reduksi data, penyajian data dan penarikan kesimpulan.

\section{PEMBAHASAN}

Mekanisme Penyelesaian Perkara Pelanggaran Kode Etik Profesi Polri Dalam Kasus Penipuan dan Penggelapan oleh Oknum Polri

Tindak perbuatan yang dilakukan AIPTU M dengan melakukan suatu tindak pidana penipuan dan penggelapan sesuai pasal 372 KUHP (perbuatan mengambil barang milik orang lain sebagian atau seluruhnya dimana penguasaan atas barang itu sudah ada pada pelaku) dan pasal 378 KUHP (dengan maksud untuk menguntungkan diri sendiri atau orang lain secara melawan hukum, dengan memakai nama palsu atau martabat palsu dengan tipu muslihat, ataupun rangkaian

\footnotetext{
Nopember 2018, (22.30 wita)

${ }^{53} \mathrm{http}$ ///andirustandi.com/baca/386/Metode-Penelitian-Hukum-Empiris-dan-Normatif.html, 22 
kebohongan, menggerakkan orang lain untuk menyerahkan barang sesuatu kepadanya, atau supaya memberi hutang maupun menghapuskan piutang, adalah suatu tindakan yang tidak mendukung standar perilaku profesional sebagaimana ditetapkan dalam Peraturan Perilaku seorang anggota Polri dan dapat menurunkan tingkat kepercayaan masyarakat serta menurunkan harkat martabat institusi Polri. Terkait permasalahan pelanggaran pidana yang dilakukan oleh AIPTU M, sesuai laporan pengaduan Saksi Korban An. NOERANA dengan menerbitkan Laporan Polisi Nomor: LP/5.A/VII/2018/Si Propam, tanggal 27 Agustus 2018 tentang adanya dugaan pelanggaran disiplin/pidana/kode etik yang dilakukan oleh AIPTU M, NRP 72100xxx, setelah melakukan penyelidikan sesuai Surat Perintah Nomor: Sprin/05/VIII/HUK.12.10/2018/Si Propam, tanggal 30 Agustus 2018, kepada korban An. NOERANA diarahkan agar melaporkan kembali pengaduannya ke Sentra Pelayanan Kepolisian Terpadu (SPKT) Polres Banjarbaru dikarenakan ditemukannya unsur pidana dalam pelanggaran yang dilakukan oleh AIPTU M, namun yang bersangkutan tidak mau melaporkan kasus pidananya dan hanya berharap disidangkan disiplin saja agar bisa tercapai perdamaian (win-win solution) antara korban dan Pelaku AIPTU M dengan penengah ANKUM (Atasan Hukum) dari Pelaku dalam menjatuhkan sanksi kepada pelaku. Hal ini sesuai dengan pernyataan Riduan Syahrani bahwa pelaksanaan hukum dalam kehidupan masyarakat sehari-hari mempunyai arti yang sangat penting karena apa yang menjadi tujuan hukum justru terletak pada pelaksanaan hukum itu. ${ }^{54}$ Padahal sesuai dengan Surat Edaran Kapolri Nomor: SE/6/V/2014 tentang Tekhnis Pelaksanaan Penegakan Pelanggaran Kode Etik Profesi Polri bahwa agar fungsi Propam segera melimpahkan ke Fungsi Reskrim terhadap hasil pemeriksaan apabila ditemukan bukti permulaan yang cukup suatu perbuatan tindak pidana yang dilakukan oleh personil Polri, sesuai ketentuan hukuman disiplin tidak menghapuskan tuntutan pidana. Adapun Tata Cara Penyelesaian Pelanggaran disiplin di Institusi Polri sesuai dengan Perkap Kapolri Nomor 2 Tahun 2016

\footnotetext{
${ }^{54}$ Riduan Syahrani, 2011, Rangkuman Intisari Ilmu Hukum, Bandung: Citra Aditya Bakti, hlm. 181.
} 
tentang Penyelesaian Pelanggaran Anggota Polri tertuang dalam Bab III, Bagian I Pasal 33 yang berbunyi :

Penyelesaian perkara pelanggaran dilaksanakan melalui tahap

a. Laporan atau pengaduan

Laporan atau pengaduan sebagaimana dimaksud dalam Pasal 33 huruf a, merupakan dasar pemeriksaan dalam penyelesaian pelanggaran disiplin anggota Polri, laporan atau pengaduan sebagaimana dimaksud pada ayat (1) dilakukan oleh setiap orang baik lisan maupun tertulis kepada petugas yang berwenang terkait adanya pelanggaran disiplin yang dilakukan oleh anggota Polri dan Laporan Polisi Petugas polri. Fungsi Propam yang dituangkan dalam bentuk tertulis dalam buku register dan kepada pelapor diberikan Surat Tanda Penerimaan Laporan Polisi model B, laporan atau pengaduan perkara pelanggaran disiplin dapat dilakukan dengan dasar : tertangkap tangan, temuan oleh petugas, laporan Paminal dan laporan masyarakat.

b. Pemeriksaaan pendahuluan

Pemeriksaan pendahuluan sebagaimana dimaksud dalam pasal 33 huruf $b$, diawali dengan melakukan penyelidikan untuk menentukan ada atau tidak terjadinya pelanggaran disiplin dan untuk mengumpulkan bukti permulaan yang cukup guna pemeriksaan lebih lanjut, anggota Polri yang berdasarkan bukti yang cukup melakukan pelanggaran disiplin dapat diberhentikan sementara dari jabatannya, tidak boleh dimutasikan, dan tidak mengikuti Pendidikan pengembangan karier, sampai adanya rekomendasi rehabilitasi dari fungsi Propam.

c. Pemeriksaan didepan sidang disiplin

Sidang disiplin sebagaimana dimaksud dalam pasal 33 huruf c dilaksanakan paling lambat 30 (tiga puluh) hari setelah Ankum menerima DP3D (daftar pemeriksaan penegakan pelanggaran disiplin) dari Fungsi Propam, sidang disiplin bersifat permanen, keputusan hukuman disiplin bersifat final tidak dapat disidangkan kembali untuk kasus yang 
korbannya sama, untuk korban berbeda masih bisa untuk disidangkan ditingkatan yang lain.

d. Penjatuhan hukuman disiplin

Penjatuhan hukuman disiplin sebagaimana dimaksud dalam pasal 33 huruf d diputuskan dalam siding disiplin oleh pimpinan sidang disiplin setelah mendengarkan dan atau memperhatikan keterangan saksi, ahli, petunjuk dan terduga pelanggar. Dalam penjatuhan hukuman disiplin pimpinan sidang perlu mempertimbangkan riwayat jabatan, karier dan hak yang akan didapat oleh terduga pelanggar dalam tempo 1 tahun kedepan, pengulangan (resedive) dan perilaku sehari hari pelanggar disiplin, terwujudnya rasa keadilan dan mampu menimbulkan efek jera serta tetap menjunjung tinggi hak asasi manusia, dan keyakinan pimpinan sidang, fakta persidangan serta didukung dengan pembuktian.

e. Pelaksanaan hukuman

Pelaksanaan hukuman disiplin sebagimana dimaksud dalam pasal 33 huruf e berlaku sejak tanggal ditetapkan oleh Ankum atau atasan Ankum dengan putusan yang berkekuatan hukum tetap, untuk pengawasan sebagaimana dimaksud pada ayat 2 dilaksanakan pada saat 6 bulan setelah menjalani hukuman dan diterbitkanya Keputusan Hukuman Disiplin, dalam hal terhukum sudah selesai menjalankan hukuman dan pengawasan, Ankum wajib mengajukan permohonan rekomendasi penilaian status (pengembalian hak/rehabilitasi personil) kepada fungsi Propam.

f. Pencatatan dalam data personil perseorangan

Pencatatan sebagaimana dimaksud dalam pasal 33 huruf $\mathrm{f}$ merupakan pencatatan setiap penjatuhan tindakan disiplin maupun hukuman disiplin dilakukan pada buku Pencatatan Data Personil Perseorangan yang dijadikan masukan bagi pengisian Riwayat Hidup Personil Perseorangan (RHPP), pencatatan dilakukan oleh Propam dan Ankum.

Sesuai dengan Pasal 5 huruf (a)PP RI nomor 2 tahun 2003 tentang peraturan disiplin anggota Polri yang berbunyi : anggota polri dilarang 
"Melakukan hal-hal yang dapat menurunkan kehormatan dan martabat negara pemerintah atau polri”.Unsur Anggota Kepolisian Negara Republik Indonesia bahwa Terduga pelanggar AIPTU M, NRP 72100xxx adalah anggota Polri yang bertugas di Polsek Aluh-Aluh kesatuan Polres Banjarbaru. Maka unsur Anggota kepolisian Negara Republik Indonesia telah terpenuhi.Unsur" Melakukan hal-hal yang dapat menurunkan kehormatan dan martabat negara pemerintah atau polri "Bahwa Terduga pelanggar AIPTU M Nrp 72100xxx Jabatan Ba Polsek aluh-aluh kesatuan Polres Banjarbaru selasa tanggal 13 Maret 2018 dan pada hari selasa 3 Juli 2018, AIPTU M merental mobil milik NOERANA sebanyak 2 (dua) unit yaitu Daihatsu pick up grand max DA 9419 PI, tahun 2015, warna putih, atas nama berinisial SRE alamat, komplek wengga trikora raya, blok x no xx rt xx/07 landasan ulin kota Banjarbaru dan Mitsubishi mirage DA 7071 PL, warna hitam mika, no rangka MMBXNA03AGH012442, no mesin 3A92UCY5487, atas nama pemilik berinisial CV. CB alamat Mustika Indah blok x no. xx rt.xx/06 guntung manggis landasan ulin banjarbaru digadaikan disandakan kepada seseorang di kurau pulau sari kab.tala yng bernama berinisial TR sebesar Rp.15.000.000,00(lima belas juta rupiah) mobil Mitsubishi mirage DA 7071 PL, warna hitam mika, no rangka MMBXNA03AGH012442, no mesin 3A92UCY5487, mobil tersebut juga digadaikan oleh sudara M kepada seseorang yang bernama berinisial DJ F menurut pengakuan saudara $\mathrm{M}$ digadaikan sebesar Rp.25.000.000,00 (dua puluh lima juta rupiah) serta mobil tersebut berada di tanjung kab.tabalong sampai saat ini tidak dikembalikan kepada pemiliknya atas perbuatan saudara terduga pelanggar AIPTU M Nrp 72100xxx tersebut telah merugikan masyarakat terutama pemilik mobil rental tersebut baik moril maupun materiil"Maka unsur "Melakukan hal-hal yang dapat menurunkan kehormatan dan martabat negara pemerintah atau polri" telah terpenuhi, Dengan demikian, Terduga pelanggar AIPTU M NRP 72100xxx Jabatan Ba Polsek xxx kesatuan Polres Banjarbaru patut diduga melakukan pelanggaran disiplin berupa larangan bagi anggota polri yaitu "Melakukan hal-hal yang dapat menurunkan kehormatan dan martabat negara pemerintah atau polri"sebagaimana dimaksud dalam pasal 5 huruf (a)Peraturan Pemerintah Republik Indonesia Nomor 2 tahun 2003 tentang 
Peraturan Disiplin bagi anggota polri, Oleh karena itu pemeriksa berpendapat bahwa perbuatan Terduga pelanggar AIPTU M, Nrp 72100xxx sudah memenuhi unsur-unsur yang tercantum dalam Pasal 5 huruf(a)Peraturan Pemerintah Republik Indonesia Nomor 2 tahun 2003 tentang Peraturan Disiplin bagi anggota Polri. Untuk itu perkaranya dapat diajukan ke Sidang Disiplin di Kesatuan Polres Banjarbaru. Adapun dasar hukum dari pemeriksaan terhadap terduga Pelanggar AIPTU M, NRP 72100xxx , yaitu : a) Laporan Polisi Nomor: LP/5.A/VIII/2018/Si Propam, tanggal 27 Agustus 2018; b) Surat Perintah Nomor: Sprin/05/VIII/HUK.12.10/2018/ Si Propam, tanggal 30 Agustus 2018.

Atas Pelanggaran Disiplin yang telah dilakukan oleh terduga pelanggar tersebut dimohon kepada Pimpinan Sidang Disiplin agar terduga pelanggar dijatuhkan hukuman berupa :

a. teguran tertulis;

b. penundaan mengikuti pendidikan paling singkat 6 (enam) bulan dan paling lama 1 (satu) tahun;

c. penundaan kenaikan gaji berkala paling singkat 3 (tiga) bulan dan paling lama 1 (satu) tahun;

d. penundaan kenaikan pangkat untuk paling singkat 1 (satu) periode dan paling lama 1 (satu) tahun;

e. mutasi yang bersifat demosi;

f. penempatan dalam tempat khusus paling singkat 7 (tujuh) hari dan paling lama 21 (dua puluh satu) hari.

Penjatuhan hukuman kepada pelanggar AIPTU M dalam konteks hukum pidana, menurut Simons menyebut Straaf adalah Het leed, door de strafwet als gevolg aan de overtrading van de norm verbonden, data anden schuldige bijrechterlijk vonis wordt opgelegd. Maknanya bahwa suatu penderitaan yang oleh Undang - Undang telah dikaitkan dengan pelanggaran terhadap suatu norma, yang dengan suatu putusan hakim telah dijatuhkan bagi seseorang yang 
bersalah. $^{55}$ Relevansinya dengan pelanggaran kode etik profesi Polri yang dilakukan oleh AIPTU M dengan melakukan penipuan dan penggelapan berdasar Pasal 372 KUHP (perbuatan mengambil barang milik orang lain sebagian atau seluruhnya dimana penguasaan atas barang itu sudah ada pada pelaku) dan Pasal 378 KUHP (dengan maksud untuk menguntungkan diri sendiri atau orang lain secara melawan hukum dengan memakai nama palsu atau martabat palsu dengan tipu muslihat, ataupun rangkaian kebohongan, menggerakkan orang lain untuk menyerahkan barang sesuatu kepadanya, atau supaya memberi hutang maupun menghapuskan piutang), apabila didalam proses penyidikan baik oleh penyidik Sat Reskrim ataupun Seksi Propam telah menemukan unsur pidana dan 2 (dua) alat bukti yang cukup, maka pelanggar AIPTU M akan ditingkatkan ke proses penyidikan untuk kemudian dilimpahkan berkas perkaranya ke Penuntut Umum / Kejaksaan untuk selanjutnya disidangkan di peradilan umum bukan di persidangan disiplin, setelah keputusan pidana bersifat tetap (incracht van gewidge).

\section{E. KESIMPULAN DAN SARAN}

\section{Kesimpulan}

Berkenaan penyelesaian permasalahan pelanggaran pidana yang dilakukan oleh AIPTU M, sesuai laporan Pengaduan Saksi Korban An. NOERANA, dengan menerbitkan Laporan Polisi Nomor : LP / 5.A / VIII / 2018 / Si Propam , tanggal 27Agustus 2018 tentang adanya dugaan pelanggaran disiplin/pidana/kode etik yang dilakukan oleh AIPTU M, NRP 72100xxx, setelah melakukan penyelidikan sesuai Surat Perintah Nomor : SPrin / 05 / VIII /HUK.12.10/ 2018 / Si Propam, tanggal 30 Agustus 2018, kepada korban An. NOERANA diarahkan agar melaporkan kembali pengaduannya ke Sentra Pelayanan Kepolisian Terpadu (SPKT) Polres Banjarbaru, dikarenakan ditemukannya unsur pidana dalam pelanggaran yang dilakukan oleh AIPTU M, namun yang bersangkutan tidak mau melaporkan kasus pidananya dan hanya berharap disidangkan disiplin saja,

55 PAF Lamintang dan Theo Lamintang, 2012, Hukum Penitensier Indonesia, Jakarta: Sinar Grafika, hal. 34 
padahal sesuai dengan Surat Edaran Kapolri Nomor : SE/6/V/2014 tentang Tekhnis Pelaksanaan Penegakan Pelanggaran Kode Etik Profesi Polri bahwa agar Fungsi Propam segera melimpahkan ke Fungsi Reskrim terhadap hasil pemeriksaan apabila ditemukan bukti permulaan yang cukup suatu perbuatan tindak pidana yang dilakukan oleh personil Polri, sesuai ketentuan hukuman disiplin tidak menghapuskan tuntutan pidana, Sidang disiplin sebagaimana setelah Ankum menerima DP3D (daftar pemeriksaan penegakan pelanggaran disiplin) dari Fungsi Propam, sidang disiplin bersifat permanen, keputusan hukuman disiplin bersifat final tidak dapat disidangkan kembali untuk kasus yang korban sama, untuk korban berbeda masih bisa untuk disidangkan ditingkatan yang lain.

\section{Saran}

Guna mendapatkan Keputusan dan Kepastian Hukum atas Pelanggaran Pidana/kode etik yang dilakukan oleh AIPTU M, terduga pelanggar dihadapkan pada sidang disiplin karena dipersangkakan telah melanggar peraturan disiplin berupa setiap anggota Polri dilarang "Melakukan hal-hal yang dapat menurunkan kehormatan dan martabat negara pemerintah atau polri.", sebagaimana dimaksud dalam Pasal 5 huruf(a) PP RI Nomor 2 tahun 2003 tentang peraturan disiplin bagi anggota Polri,dan dijatuhi hukuman berupa mutasi yang bersifat demosi sesuai Keputusan Hukuman Disiplin Nomor : Kep / 9 / IX / 2018/ Seksi Propam Polres Banjarbaru, terkait adanya korban lain yang melaporkan permasalahan yang sama melalui jalur perkara pidana, sampai dengan sekarang Sat Reskrim Polres Banjarbaru masih melakukan penyidikan, pengumpulan alat bukti dan pemeriksaan saksi-saksi, melaksanakan gelar perkara untuk naik penyidikan dan meminta pendapat, saran hukum, kepada korban sebagai pelapor nantinya diberikan haknya berupa Surat Tanda Penerimaan Laporan (STPL) dan Surat Pemberitahuan Perkembangan Hasil Penyidikan (SP2HP) apabila sudah dinyatakan 2 (dua) bukti permulaan yang cukup dan layak naik ke penyidikan oleh penyidik Sat Reskrim Polres Banjarbaru karena terpenuhinya unsur-unsur pidana pada Pasal KUHP yang diterapkan. 


\section{DAFTAR PUSTAKA}

\section{BUKU}

A Kadarmanta, 2011, Membangun Kultur Kepolisian, Jakarta: Forum Media Utama.

PAF Lamintang dan Theo Lamintang, 2012, Hukum Penitensier Indonesia, Jakarta: Sinar Grafika

Riduan Syhrani, 2011, Rangkuman intisari Ilmu Hukum, Bandung: Citra Aditya Bakti

\section{PERATURAN PERUNDANG-UNDANGAN}

Undang-Undang Republik Indonesia Nomor 2 Tahun 2002 Tentang Kepolisian Negara Republik Indonesia.

Peraturan Pemerintah Republik Indonesia Nomor 1 Tahun 2003 Tentang Pemberhentian Anggota Polri.

Peraturan Pemerintah Republik Indonesia Nomor 2 Tahun 2003 Tentang Peraturan Disiplin Anggota Polri.

Peraturan Pemerintah Republik Indonesia Nomor 3 Tahun 2003 Tentang Pelaksanaan Teknis Institusional Peradilan Umum bagi Anggota Polri.

Peraturan Kepala Kepolisian Negara Republik Indonesia Nomor 14 Tahun 2011 Tentang Kode Etik Profesi Polri.

Peraturan Kepala Kepolisian Negara Republik Indonesia Nomor 19 Tahun 2012 Tentang Organisasi dan Tata Kerja Komisi Kode Etik Polri.

Peraturan Kepala Kepolisian Negara Republik Indonesia Nomor 2 Tahun 2016 Tentang Penyelesaian Pelanggaran Disiplin Anggota Polri.

Surat Edaran Kapolri Nomor 6 Tahun 2014 Tentang Teknis Pelaksanaan Penegakkan Pelanggaran Kode Etik Profesi Polri.

\section{INTERNET}

https://assets.publishing.service.gov.uk/government/uploads/system/uploads/attac hment_data/ file/330235/MisconductPerform AttendanceJuly14.pdf,22 Nopember 2018, (22.30 wita).

http://www.iosrjournals.org/iosrjhss/papers/Vol.\%2023\%20Issue6/Version2/A2306020109.pdf, 22 Nopember 2018, (22.30 wita). 
https://www.hukumonline.com/klinik/detail/lt4ceb3048897ea /penggelapandan-penipuan, 22 Nopember 2018, (22.30 wita).

http://andirustandi.com/baca/386/Metode-Penelitian-Hukum-Empiris-danNormatif.html, 22 Nopember 2018, (22.30 wita). 